Article

\title{
Environmental Effects of Eco-Driving on Courier Delivery
}

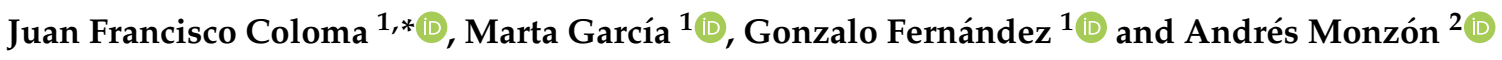 \\ 1 Department of Construction, University of Extremadura, 06071 Badajoz, Spain; martagg@unex.es (M.G.); \\ gfernandjk@alumnos.unex.es (G.F.) \\ 2 Transport Research Centre (TRANSyT), Universidad Politécnica de Madrid, 28040 Madrid, Spain; \\ andres.monzon@upm.es \\ * Correspondence: jfcoloma@unex.es; Tel.: +34-927-251-647
}

Citation: Coloma, J.F.; García, M.;

Fernández, G.; Monzón, A.

Environmental Effects of Eco-Driving on Courier Delivery. Sustainability 2021, 13, 1415. https://doi.org/ $10.3390 /$ su13031415

Academic Editors:

Hernán Gonzalo-Orden and

Heriberto Pérez-Acebo

Received: 25 November 2020

Accepted: 25 January 2021

Published: 29 January 2021

Publisher's Note: MDPI stays neutral with regard to jurisdictional claims in published maps and institutional affiliations.

Copyright: (c) 2021 by the authors. Licensee MDPI, Basel, Switzerland. This article is an open access article distributed under the terms and conditions of the Creative Commons Attribution (CC BY) license (https:/ / creativecommons.org/licenses/by/ $4.0 /)$.

\begin{abstract}
In recent years, eco-driving has proven to be an effective tool for reducing fuel consumption and greenhouse gas (GHG) emissions. Until now, most research carried out has focused on ordinary drivers applying eco-driving techniques on their usual routes. However, there is little research on professional driver couriers. This research is aimed at analyzing the effects that eco-driving has on fuel consumption and GHG emissions on courier deliveries in small cities such as Caceres (Spain). For this purpose, a real-life experiment was performed with professional drivers with Spanish post vans from the public sector company Correos. In the first period, driving was under normal conditions (non-eco), and after a theoretical training eco-driving course, there was a second driving period (eco). Driving parameters (speeds, accelerations, $\mathrm{rpm}$, and consumptions) were recorded on all trips to analyze how effective the eco-driving was. The research concluded that eco-driving training does not correlate with more sustainable driving for professional drivers under pressure with the need to deliver packages on time. However, there is a trend in fuel savings when using higher capacity routes.
\end{abstract}

Keywords: eco-driving; courier delivery; professional driver; $\mathrm{CO}_{2}$ emissions; fuel consumption

\section{Introduction}

The transport sector accounts for $25 \%$ of total greenhouse gas (GHG) emissions and almost $40 \%$ of those are from different sectors. By categories of transport, road transport represents almost $95 \%$ of emissions, while those in other categories are lower [1]. Cars and vans accounted for $72.6 \%$ of GHG emissions from road transport in 2016 [2].

The Paris Agreement [3] set a goal of reducing GHG emissions by $40 \%$ in $2030 \mathrm{com}$ pared to 1990. In order to achieve this goal, the United Nations [4] warned that from 2020 carbon emissions will have to be reduced at a rate of $7.6 \%$ per year to meet the goal of limiting the increase in global average temperatures to 1.5 degrees above pre-industrial levels.

At COP-25 in Madrid (Conference of Parties of the United Nations Framework Convention on Climate Change) [5], 73 States, including Spain, have committed to being carbon neutral by 2050. For this purpose, Spain has set itself to reduce $\mathrm{CO}_{2}$ emissions by one-third in the next decade, by doubling consumption of renewable energy by 2030.

In Spain, road transport is the main category of transport for both passengers and freight, representing more than $80 \%$ of total mobility nationally [6]. There are specifically national circumstances that have led to an increase in the share of the road transport category. First, there is the dispersed urban growth model in the case of passenger mobility. Second, it is a peripheral country in terms of freight mobility as it is located in the Iberian Peninsula. Furthermore, it is characterized by the preferential use of petroleum-derived fuels that represent more than $90 \%$ of total energy consumed in the transport sector in Spain [7].

GHG emissions corresponding to transport in Spain in 2014 were $77.2 \mathrm{MtCO}_{2}$-eq [8], having increased by almost 50\% since 1990 due to increased demand for the mobility of passengers and goods. 
Therefore, reducing GHG emissions is one of the goals of any country pursuing carbon neutrality by 2050. For freight transport, there are the following measures for reducing GHG emissions:

1. Fleet management system: companies which have used them have reduced emissions from their logistical processes by up to $2 \%$ each year [9].

2. Natural gas vehicles: in 2017, gas consumption grew by $9 \%$ in Spain and is expected to take off from 2020 [10].

3. Megatruck: according to a study by the European Commission [11], megatrucks (European Modular System Truck) can reduce fuel consumption by up to $20 \%, \mathrm{CO}_{2}$ by $20 \%$, and emissions of other pollutants such as NOx (nitrogen oxides) by $40 \%$.

4. Eco-driving: according to the guide on Eco-Driving of Industrial Vehicles from the Institute for the Diversification and Saving of Energy of Spain [12], eco-driving enables average savings of $10 \%$ in fuel.

\section{Literature Review}

Eco-driving techniques include how to start the engine, when to start braking the vehicle, and maintaining a suitable speed, which are concepts that reduce fuel consumption and, thus, $\mathrm{CO}_{2}$ emissions. In addition, they save both money and energy, require less maintenance, improve average speed, lessen the risk of accidents, and improve comfort. Eco-driving training programs carried out for individual drivers usually consist of two parts: theoretical and practical. In the practical part, the emphasis is on driving smoothly while maintaining a constant speed, changing gears at low revolutions per minute, and avoiding sudden acceleration/deceleration as much as possible [13].

Figure 1 shows a map made with the VOSviewer software (www.vosviewer.com) which used advanced layout and clustering techniques to show the existing relationships between keywords characterizing articles from the Scopus database. It has allowed identifying the main areas of research in eco-driving and fuel consumption.

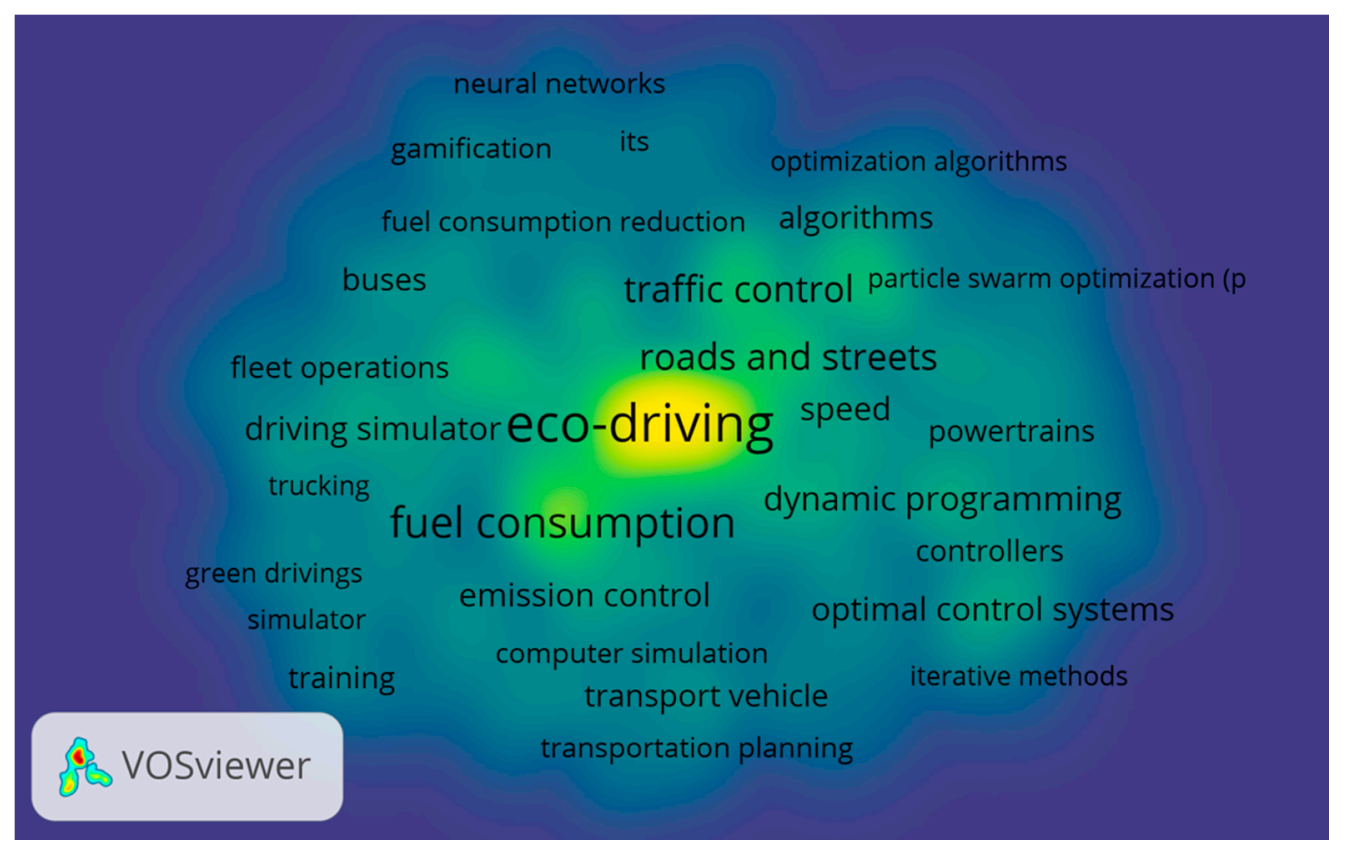

Figure 1. Map of current research trends based on co-occurrence of keywords "eco-driving and fuel consumption" from the Scopus database in the years 2010-2020.

In the literature, eco-driving techniques [14] have shown different degrees of efficiency in saving fuel and GHG emissions depending on various external factors and the learning methods used. $\mathrm{CO}_{2}$ emission reduction values range between $0.5 \%$ and $10 \%$ depending on the road type (urban roads or highways) [15]. Traffic intensity or slopes driven on are 
factors that have a direct impact on consumption [16]. Therefore, the eco-driving techniques to be used are different depending on the characteristics of the city [17], or type of road travelled [18]. Selecting an ecological route (eco-routing) has also proven to be effective in saving fuel consumption and $\mathrm{CO}_{2}$ emissions [19]. Better results have been obtained with communication between the vehicle and the infrastructure based on eco-driving guidance, increasing fuel savings to values around $20-40 \%$ [20].

Research made so far on these techniques has normally focused on non-professional drivers [21], in passenger cars on different types of road [22], vehicle or city [23]. Some research studied professional drivers, but they were not working in a courier company (Table 1).

Table 1. A summary of previous eco-driving training programs on professional drivers.

\begin{tabular}{|c|c|c|c|}
\hline $\begin{array}{l}\text { Reference } \\
\text { Number }\end{array}$ & $\begin{array}{c}\text { Year of } \\
\text { Publication }\end{array}$ & Research Type & $\begin{array}{l}\text { Fuel Consumption } \\
\text { Reduction }(\%)\end{array}$ \\
\hline$[24]$ & 2007 & Urban bus drivers in Greece. $15 \mathrm{~km}$ route designed for training purposes & $10-15 \%$ \\
\hline [25] & 2013 & Truck drivers in Germany & $9.5 \%$ \\
\hline [26] & 2013 & $\begin{array}{l}\text { Drivers on one bus line. Swedish public transport operator. } 54 \text { drivers, } \\
\qquad 16 \mathrm{~km} \text { route }\end{array}$ & $6.8 \%$ \\
\hline [27] & 2013 & Commercial vehicles in driving simulator experiment in Germany & $6.0 \%$ \\
\hline [28] & 2013 & $\begin{array}{c}\text { Municipal drivers in City of Calgary (Canada). Fifteen drivers from the } \\
\text { Development \& Building Approvals Business Unit }\end{array}$ & $4-10 \%$ \\
\hline [29] & 2014 & $\begin{array}{c}34 \text { professional drivers of the Urban Bus Company (EMTUSA) in the City } \\
\text { of Gijon (Spain). Period of } 12 \text { months. }\end{array}$ & $7 \%$ \\
\hline [30] & 2015 & 29 bus drivers with a simulator driver in Helsinki (Finland) & $11.6 \%$ \\
\hline [31] & 2017 & Lisbon urban bus transport operator (Portugal) & $0.3-2 \%$ \\
\hline [32] & 2017 & Public bus transport company. 3 drivers, $7.7 \mathrm{~km}$ in Novi Sad (Serbia) & $11.71 \%$ \\
\hline [33] & 2019 & 16 bus companies. 880 professional drivers in Spain & $10 \%$ \\
\hline [34] & 2019 & Driving simulator. 8 taxi drivers in China & $8.4 \%$ \\
\hline [35] & 2019 & 30 bus drivers in Belgrade (Serbia). Route length of $14 \mathrm{~km}$ & $8.61 \%$ \\
\hline [36] & 2020 & $\begin{array}{l}\text { Public metrobus systems used by } 250,000 \text { passengers every day in Turkey. } \\
\qquad 15 \text { months evaluation period }\end{array}$ & $5 \%$ \\
\hline
\end{tabular}

Table 1 summarizes the results of fuel consumption savings with eco-driving performed with different types of professional drivers. For bus drivers, these savings range from 0.3 to $2 \%$ obtained in Portugal [31] to values of $10-15 \%$ in Greece [24]. Furthermore, Ruty et al. [28] studied the efficiency of eco driving with municipal drivers in Canada, where daily savings in consumption between 4 to $10 \%$ were gained. Yao et al. [34] studied eight taxi drivers with a driving simulator in China, obtaining savings of $8.4 \%$. Nevertheless, none of these studies analyzed professional drivers from couriers driving under pressure to deliver packages on time.

Research on light commercial fleets showed a maximum fuel consumption savings of $7.6 \%$ in the U.K. [37] while in Germany negligible consumption reduction values were obtained [38]. These studies only focused on large cities, so the effect in small and noncongested cities must be researched with which the efficiency of eco-driving from these professional drivers can be compared. In light of the gap in knowledge in the literature, the objectives of this research are as follows.

1. To estimate consumption and emissions given off by couriers in normal driving and after attending a theoretical training course, with eco-driving in a small and noncongested city such as Caceres (Spain). To evaluate the reduction in fuel consumption and $\mathrm{CO}_{2}$ emissions in eco-driving.

2. To evaluate the efficient of eco-driving by road type.

3. To study through surveys, the perception of professional drivers on eco-driving techniques and how they apply them to everyday driving. 
For this purpose, the Spanish public sector courier Correos (Correos y Telégrafos S.A, https://www.correos.es) collaborated in the research. The city chosen was Caceres as it is small and non-congested.

After this introduction and literature review, Section 3 describes the methodology followed to perform the tests with professional drivers before and after attending ecodriving training. Section 4 describes the results obtained. Section 5 presents a discussion of the research and compares the results with those from other similar studies. Finally, the most outstanding conclusions from this research are included providing new ideas for future research.

\section{Materials and Methods}

Favorable results from previous research in eco-driving led to an eco-driving experiment on vehicles from professional companies in which fuel consumption has a direct impact on the financial performance of the company. To do so, a test was performed with four vehicles and five professional drivers from the company Correos in the city of Caceres.

The research was split into two phases: some field tests, and a subsequent study and analysis (Figure 2). In the first week of the field tests, drivers performed their respective routes under normal driving conditions (non-eco) and in the following week with ecodriving. In both methods of driving, the main driving data from the vehicles were recorded and stored (GPS positioning, speed, accelerations/decelerations, fuel consumption, etc.). In the second phase, a study of the data collected was made in order to analyze how effective eco-driving with professional drivers was.

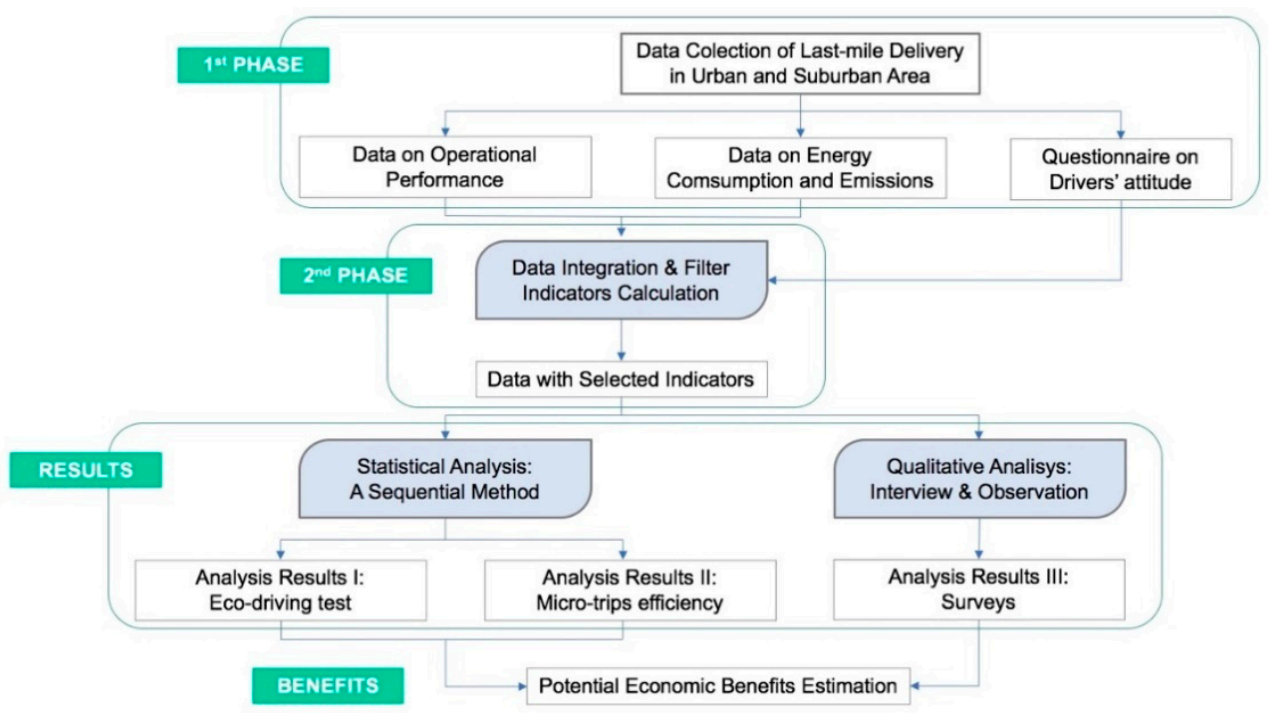

Figure 2. Research framework.

\subsection{First Phase: Collecting Data on the Activity of Vehicles on the Road}

The test ran from mid-September 2019 to mid-October of the same year. It consisted of data collected through an OBD-Key device [39] installed in the vehicles, which stored different parameters on car activity in their respective delivery days. First, the drivers drove in their usual way, i.e., as they had driven until then (non-eco). After this initial data collection, the drivers attended a training session on eco-driving in order to adopt the typical attitudes for this way of driving (see Appendix A). Once they had been trained, the drivers began eco-driving. The same driving parameters were registered for purposes of comparison. At the end of each day, each driver was asked how they felt by way of a survey.

Driver commitment is required for performing the test successfully in this kind of experiment, i.e., the human factor is crucial in terms of the results and effectiveness of applying these techniques. Additionally, it should be clarified that the routes were not 
predefined, as this is a characteristic of other studies [40]; rather, they were defined each day differently by the driver to optimize all deliveries during their working day. Therefore, they faced different traffic situations, which affected research variables such as speed, waiting times due to traffic congestion, or comfort. Driving should be carried out under different weather conditions, road types, or traffic congestion, as the research aims to obtain data on the overall efficiency of eco-driving in professional drivers.

\subsubsection{Case Study: City of Caceres, Spain}

Caceres is a city located in western Spain, with a population of approximately 96,000 inhabitants, covering an area of $30 \mathrm{~km}^{2}$. It has a significant historical past, with a high density of monuments and a unique urban morphology characteristic of the Middle Ages. As a result, it was named a World Heritage Site by UNESCO in 1986 [41].

Cars and vans represent $55 \%$ of transport within the city. Despite being hilly, pedestrian walking accounts for one-third and public transport represents only $12 \%$ of total transport [42]. The city has three peak hours: between 8:00 am and 9:00 am, the school run and the start of the working day ( $10 \%$ above average); $2: 00 \mathrm{pm}$, lunch break ( $28 \%$ above average); and between 6:00 pm and 7:00 pm, returning home (15\% above average) [43].

Sustainable growth for the city involves implementing measures that promote using public transport and pedestrian mobility. Although environmental protection and emission reduction policies have already been applied in the historic center of Caceres (pedestrianizing the historic center), pedestrian spaces that exclude car movements must be extended to reach new and better sustainability goals.

\subsubsection{Routes and Traffic Conditions}

Caceres is a small city that can be crossed in less than $15 \mathrm{~min}$. As mentioned above, the routes do not adhere to defined itineraries, but rather follow that of a professional driver on a normal delivery day. That is distributed throughout the city, travelling along different types of urban roads (Figure 3).

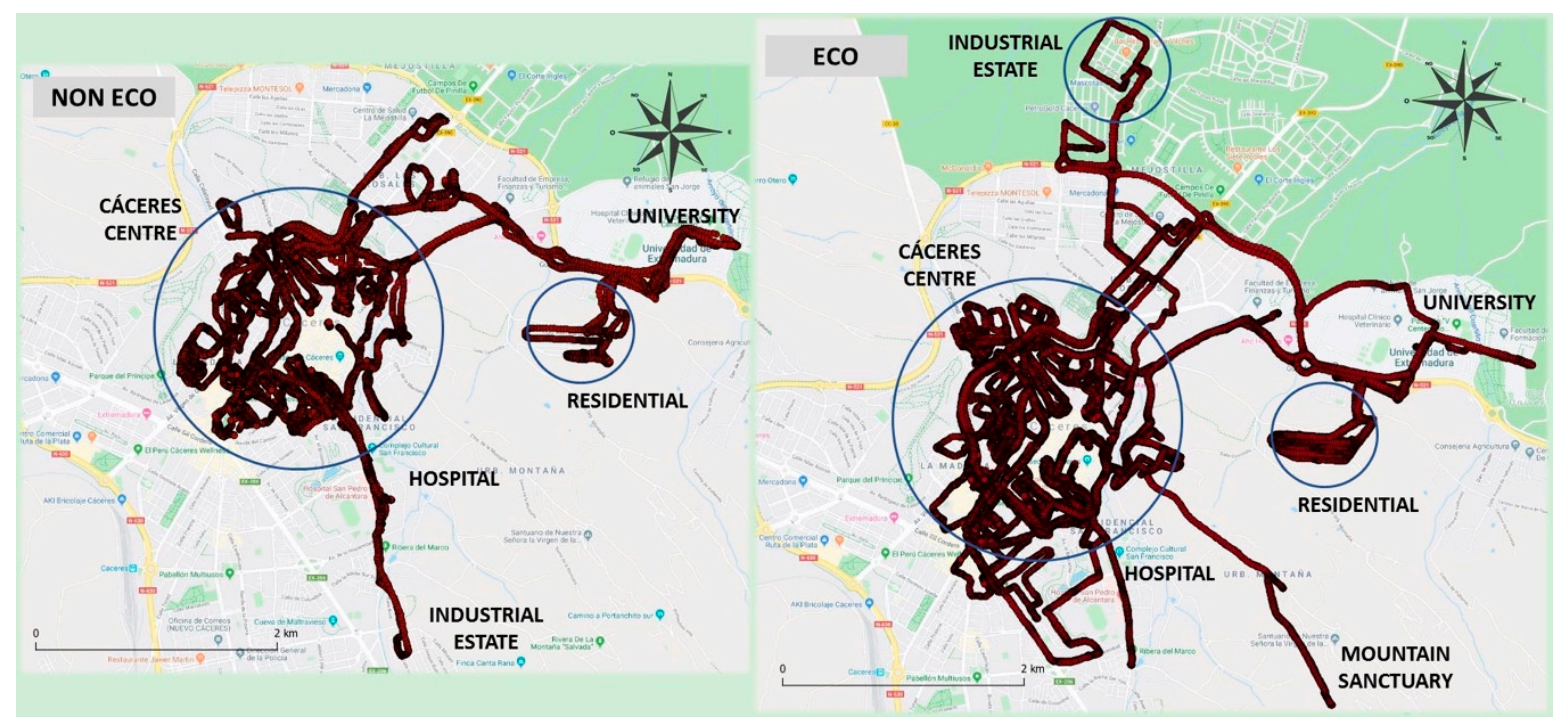

Figure 3. Global vision of the routes of one of the drivers with normal driving (non-eco) (left) and eco-driving (right).

Five different types of road (Figure 4) [44] are defined to characterize the different sections and analyze specific shorter routes (micro-trips):

1. Local street: this type of urban road can be seen inside the city. The road has one lane per direction, with no median or parking spaces. The speed limit is $50 \mathrm{~km} / \mathrm{h}$ and it is usually congested. 
2. Urban collector: a road that surrounds the center of the city and connects its hubs. It is made up of two lanes each way, a median, and with parking spaces on each side. The speed limit ranges between $30 \mathrm{~km} / \mathrm{h}$ and $50 \mathrm{~km} / \mathrm{h}$ and it is sometimes congested.

3. Perimeter road: former city bypass now integrated into the urban network. It has a dual carriageway with two lanes in each direction separated by a double continuous line or median. The speed limit is $50 \mathrm{~km} / \mathrm{h}$, and there is hardly any traffic congestion.

4. Bypass: an outer ring road surrounding the outskirts of the city. Intersections are arranged with roundabouts and pedestrian crossings are regulated through traffic lights. Speed limits are between 40 and $80 \mathrm{~km} / \mathrm{h}$. It is never congested.

5. Interurban road: roads located outside the boundaries of the urban area that connect external points to it, whether they are smaller population centers, industrial centers or other national roads or highways. Speed limits vary between 50 and $90 \mathrm{~km} / \mathrm{h}$ and traffic usually flows very well with no congestion.

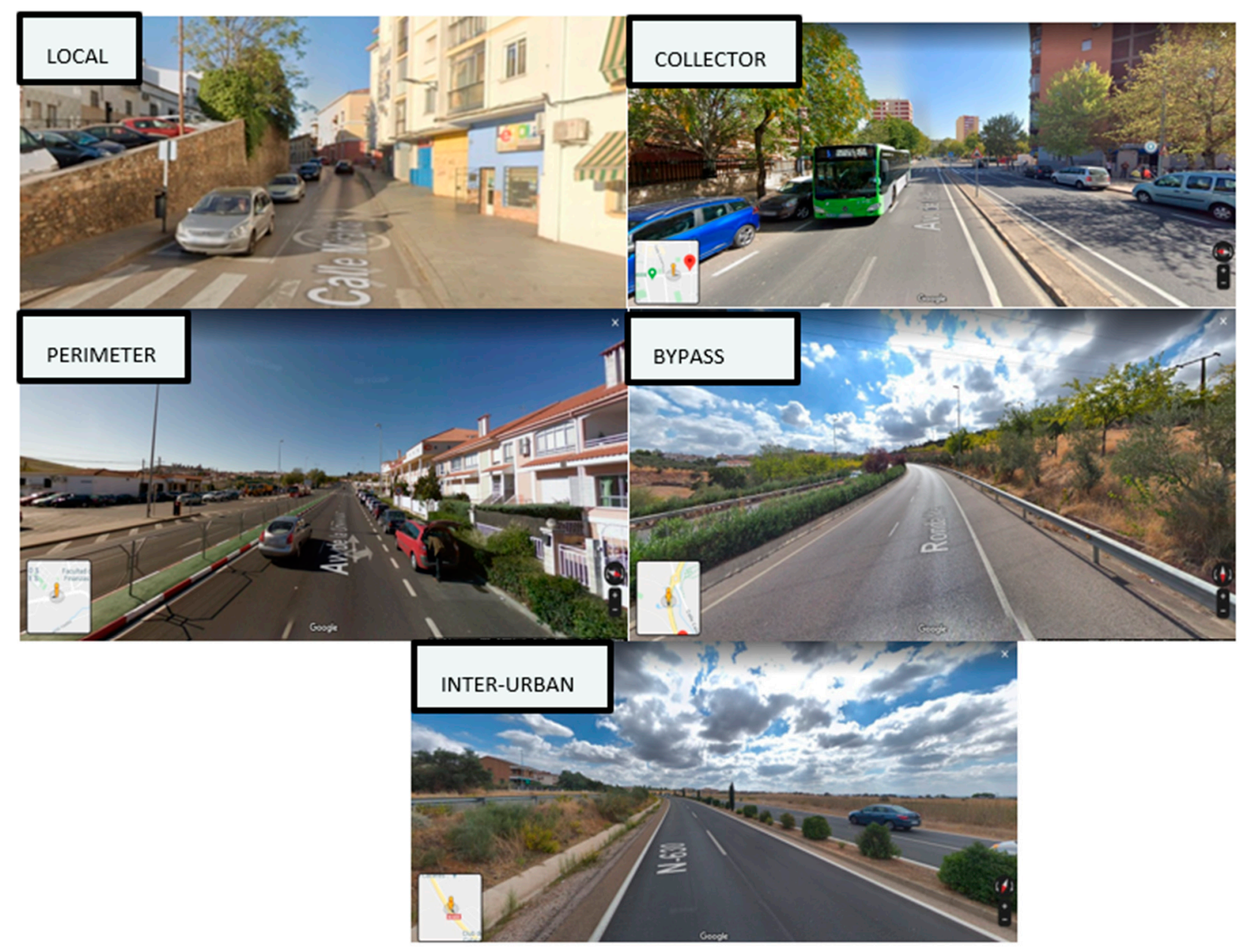

Figure 4. Road types travelled (source: Google Maps).

\subsubsection{Driver Selection, Eco-Driving Training and Dates}

To carry out the experiment, five drivers were selected from the delivery company of Correos in Caceres. All drivers were male between the ages of 35 and 60, so the sample was representative in terms of age, but not in gender. During the first week, the trips these drivers made while driving as usual (non-eco) were recorded. Subsequently, the selected drivers received theoretical training on eco-driving techniques in order to implement them the following week. All trips made with eco-driving were recorded in the same way as previously with "non-eco" driving. 
Work hours were divided into two time bands corresponding to the morning and afternoon work shifts: the first one was from 7:00 am to 2:00 pm and the second was between 2:00 pm and 9:00 pm. Four drivers performed the experiment in the first shift, while there was only one driver in the afternoon.

The experiment with standard driving (non-eco) took place between 23 September and 2 October 2019, and eco-driving was studied between 9 and 18 October of the same year. Between both periods, eco-driving training was given to the drivers.

\subsubsection{Collection of Experimental Data}

In the field test, commercial vehicles were used, and in this case they were diesel vans with similar technical characteristics. Three of them belonged to the Kangoo range from the Renault make and the fourth was the Partner range from Peugeot (Table 2). Commercial vehicles represent approximately $20 \%$ of cars and vans in service in Caceres [45].

Table 2. Technical characteristics of the vehicles used in the research [46].

\begin{tabular}{ccc}
\hline Features & Peugeot & Renault \\
\hline Full name & PARTNER 1.6 HDi 75 & KANGOO 1.5 DCi 70 \\
Gear shift type & Manual (5) & Manual (5) \\
Maximum authorized mass & 1960 & 2956 \\
HP power & 75 & 70 \\
Dimensions $(\mathrm{L} \times \mathrm{W} \times \mathrm{H})(\mathrm{mm})$ & $4380 \times 2890 \times 1801$ & $4213 \times 2133 \times 1799$ \\
Seats & $2-5$ & $2-5$ \\
Emissions $\left(\mathrm{g}\right.$ de $\left.\mathrm{CO}_{2} / \mathrm{km}\right)$ & 143 & 147 \\
Classification by relative consumption & $\mathrm{C}$ & $\mathrm{D}$ \\
\hline
\end{tabular}

\subsubsection{Measurement of Variables}

Modern vehicles enable many aspects of running a vehicle to be monitored and visualized through the on-board diagnostic $(\mathrm{OBD})$ system. This is carried out using electronic control units with which the engine, transmission, brakes, and other functions can be managed.

The OBD-key is a device that plugs into the vehicle's data link connector with which information from the vehicle's OBD can be captured. This information is sent through a mobile application [47] to a smartphone via Wi-Fi (frequency of $1 \mathrm{~Hz}$ ) where the information is stored and subsequently transferred to a computer to process all the recorded data. With this device, 128 instantaneous parameters can be obtained such as GPS position, speed, acceleration, revolutions per minute (rpm), fuel consumption $(\mathrm{L} / \mathrm{s})$, and $\mathrm{CO}_{2}$ emissions $(\mathrm{g} / \mathrm{s})$. The operating procedure is shown in Figure 5.

The effects of eco-driving will be evaluated first by comparing fuel consumption and $\mathrm{CO}_{2}$ emissions and secondly, by analyzing the driving parameters with the highest influence on fuel consumption. According to Coloma et al. [48], and subsequently Lois et al. [49], the parameters which account for over $80 \%$ of fuel consumption are slope, average speed, average rpm, and average accelerations and decelerations. In addition to these values, other parameters are recorded to characterize different routes by location (GPS positioning) and traffic situation (95th percentile of instant recorded speed). The parameters listed below were finally used for the analysis before and after the drivers underwent eco-driving training:

1. GPS position (longitude and latitude) and distance travelled $(\mathrm{km})$.

2. Travel time $(\mathrm{h})$ and $\mathrm{V}_{95}(\mathrm{~km} / \mathrm{h})$.

3. Maximum and average speed $(\mathrm{km} / \mathrm{h})$.

4. Maximum and average rpm.

5. Maximum and average accelerations and decelerations $\left(\mathrm{m} / \mathrm{s}^{2}\right)$.

6. Fuel consumption $(\mathrm{L} / 100 \mathrm{~km})$ and $\mathrm{CO}_{2}$ emissions $(\mathrm{g} / \mathrm{km})$.

Data on fuel consumption and $\mathrm{CO}_{2}$ emissions take into account the slope value every second. However, to compare the drivers in eco and non-eco-driving mode, the slope value 
was discarded, as the average slopes obtained for all routes were $1.9 \%$ and the maximum was only $2.9 \%$.

Vehicle

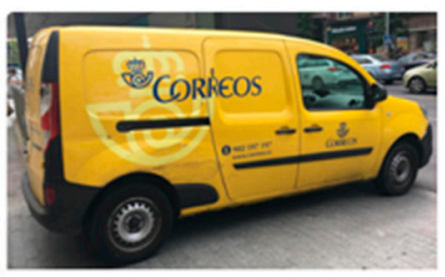

OBD-Key

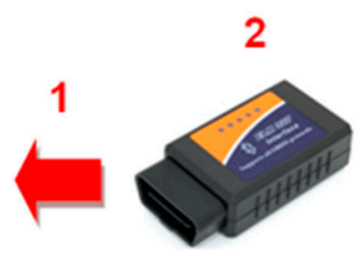

Smartphone

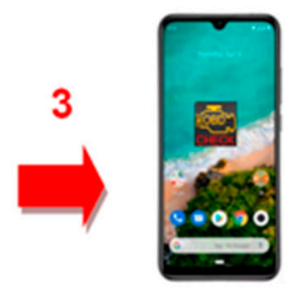

\section{Computer}

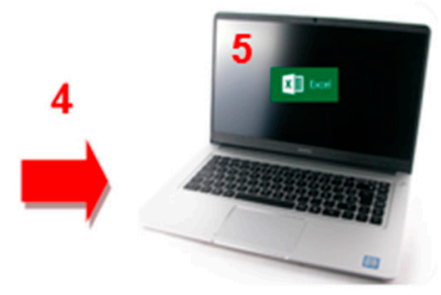

Figure 5. Outline of the data collection and storage system process.

\subsection{Second Phase: Analysis and Study of the Collected Data}

In a laboratory, the stored data were received and processed from the OBD-Key. These data were filtered to remove erroneous registrations and stops when making deliveries. Subsequently, the different selected parameters were discretized and organized in order to calculate sums, averages, weights, or unit changes. Results were obtained and enabled comparisons between parameters and formulating reliable conclusions.

Once these data were processed, several documents were created which belonged to each driver and contained all the parameters monitored by the OBD-Key and recorded per second. From this information, the representative driving parameters of each working day for each driver in both driving modes (eco and non-eco) were set out on a spreadsheet.

After these spreadsheets were created, eco and non-eco-driving among the same drivers were compared. As explained, research was mainly looking for data on fuel consumption and $\mathrm{CO}_{2}$ emissions and also to compare the parameters with the highest influence on consumption such as speed, rpm, and average acceleration/decelerations. As each driver travelled different distances and drove at different speeds, the consumption and emissions parameters weighted with respect to the time and distance travelled each day had to be obtained. In this way, fuel consumption values per $100 \mathrm{~km}(\mathrm{~L} / 100 \mathrm{~km})$ and $\mathrm{CO}_{2}$ emissions per kilometer $(\mathrm{g} / \mathrm{km})$ were found.

Later, sections of short routes made by vans (micro-trips) were analyzed with the data set obtained. For this purpose, the start and end time were obtained on different types of road travelled in the delivery routes. Geolocation analysis and storage software [50] were used to graphically represent routes and the main driving parameters at each point of the trip. With this process, the benefits of eco-driving for different types of road (micro-trips) could be studied. Figure 6 summarizes the process carried out.

Finally, a survey was carried out among drivers to assess the mood and attitude of the driver to using eco-driving techniques (see Appendix B). Once the data collection and analysis had been completed, the results showed satisfactory conclusions for this research. 


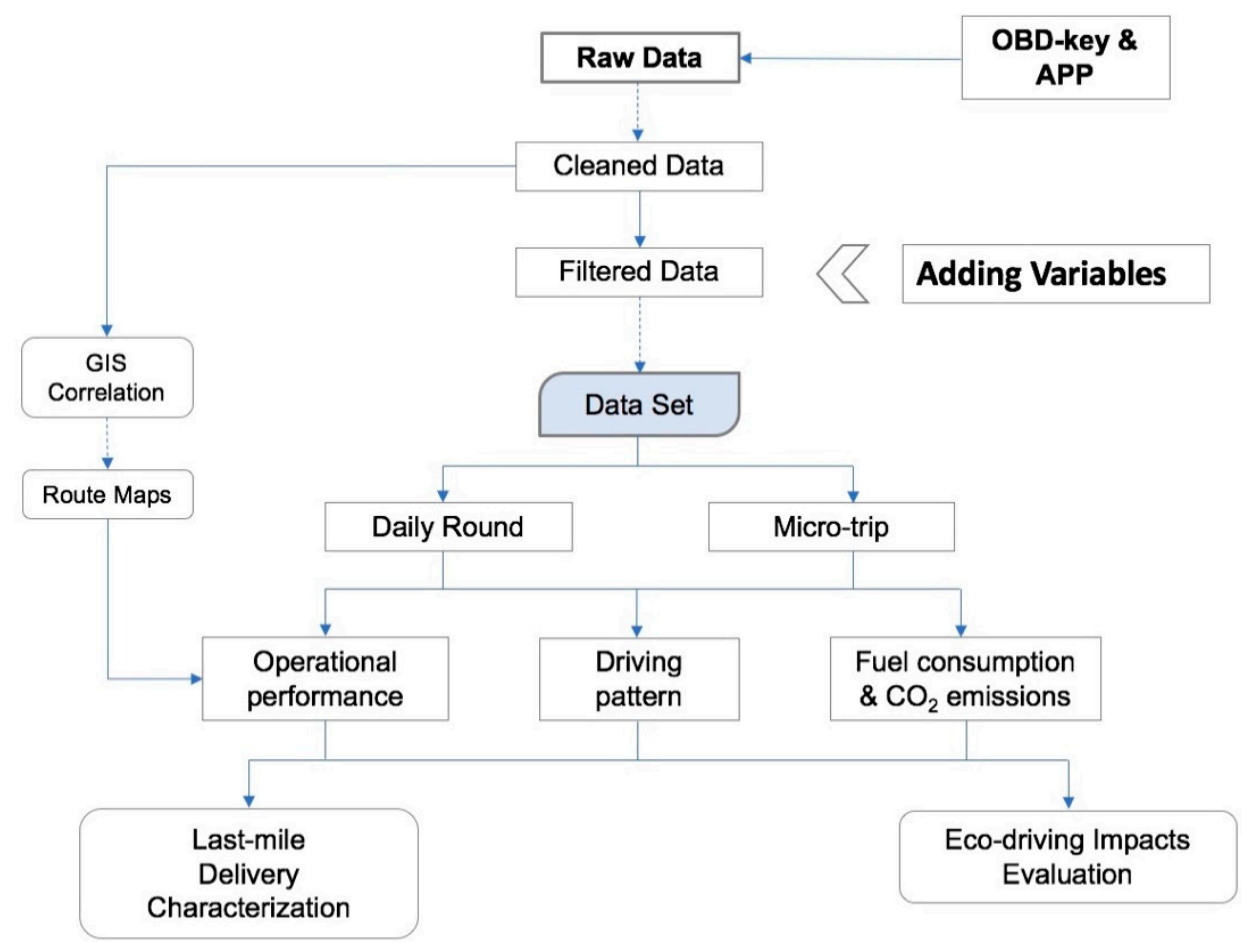

Figure 6. Analysis and study of the collected data.

\section{Results}

Statistical data from the experiment have been included in Table 3.

Table 3. Distances and time travelled. Deliveries made.

\begin{tabular}{ccccc}
\hline Driver & Driving Mode & Distance Travelled $\mathbf{( k m )}$ & Driving Time (h) & Deliveries No. \\
\hline \multirow{2}{*}{1} & Non-eco & 115.1 & 35.6 & 223 \\
& Eco-driving & 131.4 & 26.8 & 221 \\
\hline \multirow{2}{*}{2} & Non-eco & 80.1 & 11.4 & 156 \\
& Eco-driving & 215.2 & 41.3 & 363 \\
\hline \multirow{2}{*}{3} & Non-eco & 123.1 & 33.1 & 266 \\
& Eco-driving & 167.3 & 34.5 & 340 \\
\hline \multirow{2}{*}{4} & Non-eco & 96.8 & 31.7 & 328 \\
& Eco-driving & 45.8 & 11.2 & 133 \\
\hline \multirow{2}{*}{5} & Non-eco & 176.8 & 24.8 & 245 \\
& Eco-driving & 139.2 & 23.4 & 277 \\
\hline \multirow{2}{*}{ Partial } & Non-eco & 591.9 & 136.6 & 1218 \\
Sum & Eco-driving & 698.9 & 137.2 & 1334 \\
Total & Non-eco + eco & 1290.8 & 273.8 & 2552 \\
\hline
\end{tabular}

Time deliveries for eco and non-eco-driving are similar (less than an hour apart). However, in eco-driving, 100 more kilometers were driven and over 100 packages distributed. Primarily, this was not due to the driving mode, but rather to the nature and location of the deliveries made. In eco-driving, more deliveries could be made, probably due to the reduction in waiting times, either because of the traffic situation, or the needs of the final recipients.

A total of 2544 deliveries have been registered, of which $95.28 \%$ have been residential and $4.72 \%$ industrial. Regarding the ages of the recipients, we registered a total of 2424 deliveries of which $47.44 \%$ were older than 45 years and $52.56 \%$ younger. Due to new 
technologies, young people are the ones who most demand parcel services. However, in our study, the percentage of those over and under 45 years is very similar.

\subsection{Eco-Driving Test}

\subsubsection{Driving Parameters}

Table 4 shows the main driving parameters recorded by driver and for non-eco and eco-driving modes.

Table 4. Driving parameters for different drivers and driving mode.

\begin{tabular}{|c|c|c|c|c|c|c|}
\hline \multirow{2}{*}{ Parameter } & \multirow{2}{*}{$\begin{array}{l}\text { Driving } \\
\text { Mode }\end{array}$} & \multicolumn{5}{|c|}{ Driver } \\
\hline & & 1 & 2 & 3 & 4 & 5 \\
\hline \multirow{2}{*}{ Maximum speed $(\mathrm{km} / \mathrm{h})$} & Non-eco & 41.7 & 38.8 & 47.1 & 31.7 & 61.1 \\
\hline & Eco-driving & 48.5 & 51.1 & 51.8 & 30.0 & 49.2 \\
\hline \multirow{2}{*}{$\mathrm{V}_{95}(\mathrm{~km} / \mathrm{h})$} & Non-eco & 38.2 & 35.6 & 42.5 & 28.9 & 55.6 \\
\hline & Eco-driving & 44.6 & 44.5 & 47.0 & 28.3 & 44.7 \\
\hline \multirow{2}{*}{ Average speed $(\mathrm{km} / \mathrm{h})$} & Non-eco & 16.8 & 17.3 & 19.9 & 15.3 & 30.3 \\
\hline & Eco-driving & 19.5 & 18.9 & 23.7 & 15.4 & 25.8 \\
\hline \multirow{2}{*}{ Average rpm } & Non-eco & 1164 & 1619 & 1225 & 1209 & 1745 \\
\hline & Eco-driving & 1279 & 1563 & 1267 & 1286 & 1412 \\
\hline \multirow{2}{*}{ Maximum rpm } & Non-eco & 2144 & 3172 & 2849 & 1956 & 3004 \\
\hline & Eco-driving & 2348 & 3096 & 2620 & 2012 & 2366 \\
\hline \multirow{2}{*}{ Average positive acceleration $\left(\mathrm{m} / \mathrm{s}^{2}\right)$} & Non-eco & 0.6 & 0.4 & 0.7 & 0.4 & 0.9 \\
\hline & Eco-driving & 0.6 & 0.6 & 0.7 & 0.4 & 0.8 \\
\hline \multirow{2}{*}{ Average negative acceleration $\left(\mathrm{m} / \mathrm{s}^{2}\right)$} & Non-eco & -0.6 & -0.4 & -0.7 & -0.4 & -0.9 \\
\hline & Eco-driving & -0.6 & -0.7 & -0.7 & -0.4 & -0.8 \\
\hline \multirow{2}{*}{ Maximum positive acceleration $\left(\mathrm{m} / \mathrm{s}^{2}\right)$} & Non-eco & 2.1 & 1.9 & 2.9 & 1.5 & 4.1 \\
\hline & Eco-driving & 2.2 & 2.9 & 2.9 & 1.3 & 3.2 \\
\hline \multirow{2}{*}{ Maximum negative acceleration $\left(\mathrm{m} / \mathrm{s}^{2}\right)$} & Non-eco & -2.0 & -1.8 & -2.5 & -1.6 & -4.0 \\
\hline & Eco-driving & -2.3 & -2.8 & -2.6 & -1.4 & -3.5 \\
\hline
\end{tabular}

In most of the research published in the literature, eco-driving produces reductions in rpm, speed, and accelerations/decelerations [51,52]. From the results obtained, it can be concluded that only driver 5 improves his driving parameters with eco-driving. Maximum and average speeds, rpm, and accelerations increase with eco-driving in the parameters for the other four drivers. Congestion or the stress involved in delivering packages in the shortest possible time means that most professional drivers in the experiment did not obtain improvements in these parameters when eco-driving.

\subsubsection{Consumption and Emissions}

Table 5 shows estimated fuel consumption and $\mathrm{CO}_{2}$ emissions for each driver and both driving modes (non-eco and eco-driving).

Table 5. Fuel consumption and $\mathrm{CO}_{2}$ emission for driver and driving mode.

\begin{tabular}{ccccccc}
\hline \multirow{2}{*}{ Parameter } & Driving Mode & \multicolumn{5}{c}{ Driver } \\
\cline { 3 - 7 } & & $\mathbf{1}$ & $\mathbf{2}$ & $\mathbf{3}$ & $\mathbf{4}$ & $\mathbf{5}$ \\
\hline \multirow{2}{*}{ Consumption $(\mathrm{L} / 100 \mathrm{~km})$} & Non-eco & 6.71 & 6.16 & 6.15 & 8.93 & 5.99 \\
& Eco-driving & 6.26 & 6.18 & 5.54 & 8.48 & 6.95 \\
\hline \multirow{2}{*}{$\mathrm{CO}_{2}$ emissions $(\mathrm{g} / \mathrm{km})$} & Non-eco & 208.7 & 191.0 & 187.2 & 271.2 & 188.8 \\
& Eco-driving & 193.3 & 195.1 & 168.4 & 259.2 & 219.9 \\
\hline
\end{tabular}

Emission ratios differ according to the technical specifications of the vehicle, as well as fuel consumption, as each driver used different routes and drove in a different way.

Consumption and emission savings with eco-driving are represented in Figure 7. 


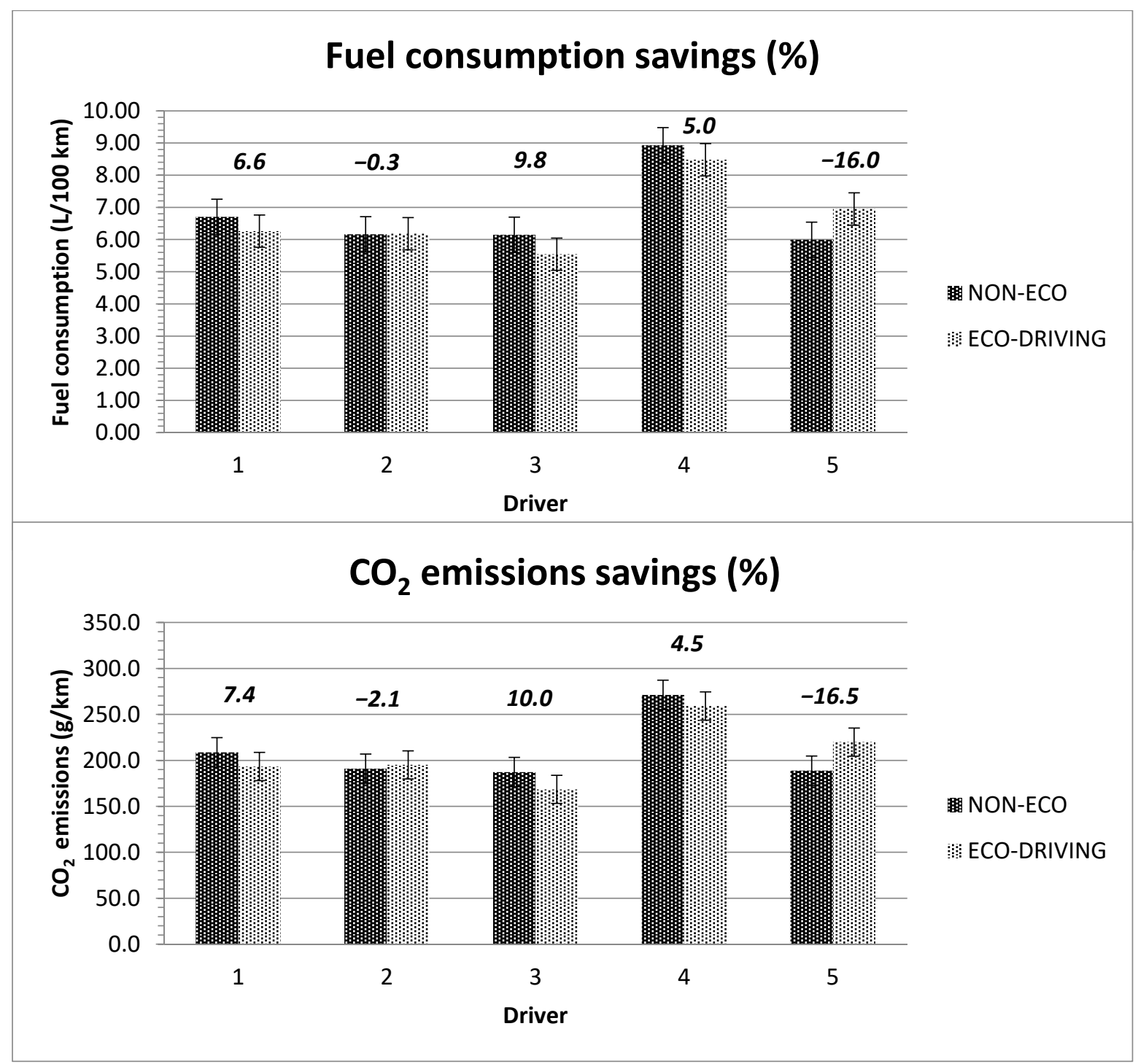

Figure 7. Savings in fuel consumption (figure up) and $\mathrm{CO}_{2}$ emissions (figure down) between non-eco and eco-driving.

Fuel consumption and $\mathrm{CO}_{2}$ emissions show that eco-driving in small cities is inefficient. With the only driver to have eco-driving parameters, there was higher average fuel consumption and $\mathrm{CO}_{2}$ emissions. Conversely, three of the other four drivers with no eco-driving parameters showed a reduction in fuel consumption and emissions. This shows that in small cities, high speeds mean short traveling times, which, in turn, reduce average fuel consumption $(\mathrm{L} / 100 \mathrm{~km})$ and average emissions. Eco-driving usually reduces speeds and acceleration, but in small cities where routes are very short, it does not sufficiently reduce instantaneous consumption, and this means longer driving times produce higher average fuel consumption $(\mathrm{L} / 100 \mathrm{~km})$ and, as a consequence, higher $\mathrm{CO}_{2}$ emissions.

\subsection{Efficiency of Eco-Driving in Micro-Trips}

An analysis by type of road travelled (local, collector, perimeter, bypass, and interurban) was performed to study how effective eco-driving professional drivers based on type of route travelled was. For this purpose, eight different small routes were selected (micro-trips), with different types of road, which were easily located and widely used by drivers in their daily deliveries. Micro-trips locations are represented in Figure 8. 


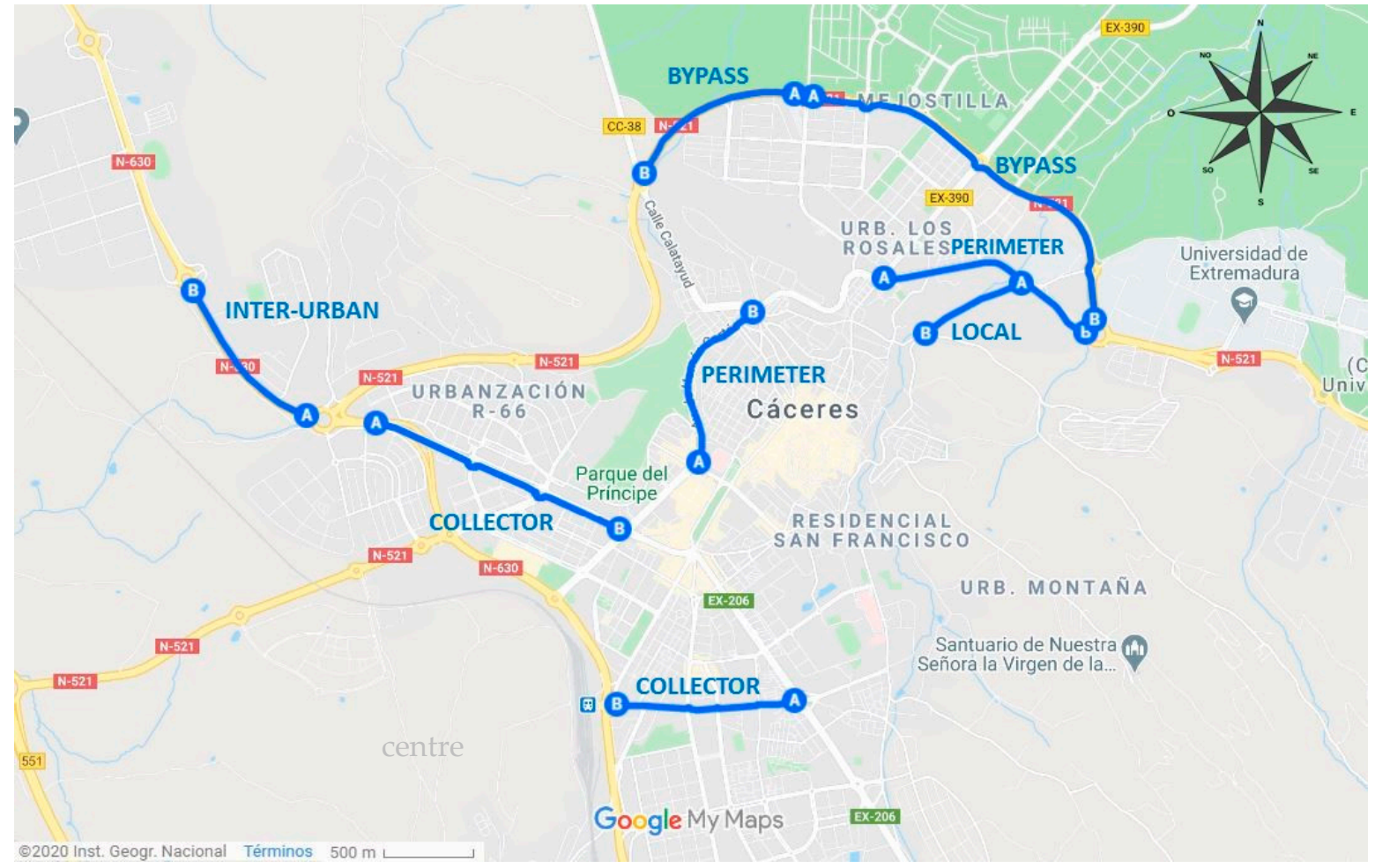

Figure 8. Micro-trips location scheme (source: Google Maps).

Selected micro-trips are routes shared by most of the drivers. An analysis was performed from the data from all drivers who had taken these routes, both in their normal style (non-eco) and in eco-driving. The results obtained were used to verify how efficient eco-driving had been by type of road travelled and not by drivers studied in the previous section. Characteristics of the selected micro-trips are attached in Table 6.

Table 6. Characteristics of the selected micro-trips.

\begin{tabular}{cccccc}
\hline Road Type. & Route No. & Description & Section Length & Speed Limit \\
\hline Local & 1 & One lane for each direction & $550 \mathrm{~m}$ & $50 \mathrm{~km} / \mathrm{h}$ \\
\hline \multirow{2}{*}{ Collector } & 2 & Two lanes each way separated by median. Parking on both sides & $600 \mathrm{~m}$ & $30-50 \mathrm{~km} / \mathrm{h}$ \\
& 3 & Two lanes each way separated by median & $900 \mathrm{~m}$ & $30-50 \mathrm{~km} / \mathrm{h}$ \\
\hline \multirow{2}{*}{ Perimeter } & 4 & Two lanes each way separated by median. Parking on both sides & $950 \mathrm{~m}$ & $50 \mathrm{~km} / \mathrm{h}$ \\
& 5 & Two lanes each way separated by median. Parking on both sides & $1200 \mathrm{~m}$ & $50 \mathrm{~km} / \mathrm{h}$ \\
\hline \multirow{2}{*}{ Bypass } & 6 & Two lanes each way separated by median & $1000 \mathrm{~m}$ & $50-80 \mathrm{~km} / \mathrm{h}$ \\
& 7 & Two lanes each way separated by median & $2200 \mathrm{~m}$ & $50-80 \mathrm{~km} / \mathrm{h}$ \\
\hline Inter-urban & 8 & Two lanes each way separated by median & $950 \mathrm{~m}$ & $80 \mathrm{~km} / \mathrm{h}$ \\
\hline
\end{tabular}

Two micro-trips have been selected for collector, perimeter, and bypass types of road. For the local and inter-urban road, only one section of these was found to provide enough data for the drivers in both driving modes.

A total of 136 deliveries have been studied (74 in non-eco and 62 in eco-driving mode). In addition, $72.2 \mathrm{~km}$ (40.1 non-eco; $32.1 \mathrm{eco}$ ) has been covered in a total of $125.35 \mathrm{~min}$ (70 in non-eco and 55.3 in eco mode). The number of kilometers and deliveries made in non-eco mode are greater than those made in eco-driving mode as drivers did not travel predetermined routes and kilometers driven in eco and non-eco mode do not need to match.

Driving parameters recorded in the micro-trips before and after eco-driving training are included in Table 7. 
Table 7. Driving parameters on selected micro-trips.

\begin{tabular}{|c|c|c|c|c|c|c|c|c|c|}
\hline & \multirow{2}{*}{ Driving Mode } & \multirow{2}{*}{$\begin{array}{c}\text { Local } \\
\text { Route } 1\end{array}$} & \multicolumn{2}{|c|}{ Collector } & \multicolumn{2}{|c|}{ Perimeter } & \multicolumn{2}{|c|}{ Bypass } & \multirow{2}{*}{$\begin{array}{c}\text { Inter-Urban } \\
\text { Route } 8\end{array}$} \\
\hline & & & Route 2 & Route 3 & Route 4 & Route 5 & Route 6 & Route 7 & \\
\hline \multirow{2}{*}{ Maximum speed (km/h) } & Non-eco & 51.4 & 39.9 & 65.9 & 56.5 & 76.9 & 86.8 & 69.5 & 88 \\
\hline & Eco-driving & 67.8 & 45.3 & 41.7 & 62.8 & 70.6 & 80.1 & 63.5 & 51.4 \\
\hline \multirow{2}{*}{ V95 (km/h) } & Non-eco & 50.5 & 37.5 & 63.6 & 52.1 & 75.4 & 84.8 & 66.2 & 86.8 \\
\hline & Eco-driving & 66.4 & 43.8 & 41.1 & 60.6 & 69.4 & 79.0 & 62.9 & 51 \\
\hline \multirow{2}{*}{ Average speed $(\mathrm{km} / \mathrm{h})$} & Non-eco & 39.6 & 24.3 & 37.2 & 34.6 & 57 & 59.1 & 50.9 & 73.6 \\
\hline & Eco-driving & 44.9 & 26.0 & 26.9 & 40.4 & 42.8 & 64.7 & 46.4 & 45.5 \\
\hline \multirow{2}{*}{ Maximum rpm } & Non-eco & 2520 & 2309 & 2296 & 2890 & 2373 & 3135 & 2885 & 2859 \\
\hline & Eco-driving & 3205 & 2633 & 2160 & 2447 & 2427 & 2592 & 2656 & 2235 \\
\hline \multirow{2}{*}{ Average rpm } & Non-eco & 1870 & 1168 & 1523 & 1800 & 1746 & 2062 & 2081 & 2154 \\
\hline & Eco-driving & 2428 & 1337 & 1424 & 1713 & 1480 & 1882 & 2089 & 1834 \\
\hline \multirow{2}{*}{ Maximum positive acceleration $\left(\mathrm{m} / \mathrm{s}^{2}\right)$} & Non-eco & 1.7 & 2.0 & 2.4 & 3.0 & 1.9 & 1.8 & 2.9 & 1.8 \\
\hline & Eco-driving & 2.2 & 3.0 & 1.1 & 2.3 & 1.9 & 1.6 & 2 & 0.8 \\
\hline \multirow{2}{*}{ Maximum negative acceleration $\left(\mathrm{m} / \mathrm{s}^{2}\right)$} & Non-eco & -1.2 & -1.5 & -2.7 & -3.4 & -2.7 & -3.2 & -2.7 & -2.7 \\
\hline & Eco-driving & -1.8 & -2.2 & -1.5 & -3.7 & -2.4 & -1.7 & -3.6 & -1.3 \\
\hline Average positive acceleration $\left(\mathrm{m} / \mathrm{s}^{2}\right)$ & Eco-driving & 0.7 & 0.7 & 0.3 & 0.8 & 0.7 & 0.6 & 0.8 & 0.3 \\
\hline \multirow{2}{*}{ Average negative acceleration $\left(\mathrm{m} / \mathrm{s}^{2}\right)$} & Non-eco & -0.5 & -0.5 & -0.7 & -0.8 & -0.8 & -0.8 & -0.8 & -0.8 \\
\hline & Eco-driving & -0.6 & -0.6 & -0.3 & -0.8 & -0.7 & -0.6 & -1 & -0.3 \\
\hline
\end{tabular}


Analyzing the results, eco-driving style can be seen in the routes with higher capacity and less congestion (bypass and inter-urban). Congested urban routes (local and collector) increase speed, rpm, and acceleration in eco mode, so using eco-driving techniques has not been viable on these types of road. Perimeter gives varying results that make it difficult to rate the driving style performed. In Route 5, there seems to be an eco-driving style, but not in Route 4.

Research made on different types of road normally indicates that eco-driving reduces speed, rpm, and accelerations [53]. However, there are other studies which show that on congested roads, eco-driving does not reduce these parameters [54]. Table 8 displays consumption and emissions estimated for the selected micro routes.

Table 8. Consumption and emissions estimation on the selected micro-trips.

\begin{tabular}{|c|c|c|c|c|c|c|c|c|c|}
\hline & \multirow{2}{*}{ Driving Mode } & \multirow{2}{*}{$\begin{array}{c}\text { Local } \\
\text { Route } 1\end{array}$} & \multicolumn{2}{|c|}{ Collector } & \multicolumn{2}{|c|}{ Perimeter } & \multicolumn{2}{|c|}{ Bypass } & \multirow{2}{*}{$\begin{array}{c}\text { Inter-Urban } \\
\text { Route } 8\end{array}$} \\
\hline & & & Route 2 & Route 3 & Route 4 & Route 5 & Route 6 & Route 7 & \\
\hline \multirow{2}{*}{ Consumption (L/100 km) } & Non-eco & 2.1 & 2.2 & 8.8 & 6.1 & 8.4 & 4.6 & 2.7 & 4.5 \\
\hline & Eco-driving & 2.9 & 3.1 & 10.1 & 6.0 & 8.4 & 4.4 & 2.6 & 4.2 \\
\hline \multirow{2}{*}{$\mathrm{CO}_{2}$ emissions $(\mathrm{g} / \mathrm{km})$} & Non-eco & 63.6 & 70.7 & 154.8 & 188.5 & 109.4 & 146.1 & 77.8 & 112.5 \\
\hline & Eco-driving & 88.2 & 96.4 & 187.4 & 186.3 & 109.3 & 138.5 & 77.6 & 97.0 \\
\hline
\end{tabular}

Fuel consumption and $\mathrm{CO}_{2}$ emissions are in keeping with the driving parameters performed. Routes with higher capacity and less congestion (bypass and inter-urban) reduce fuel consumption and $\mathrm{CO}_{2}$ emissions when driving in eco mode. These savings with eco-driving are represented in Figure 9.

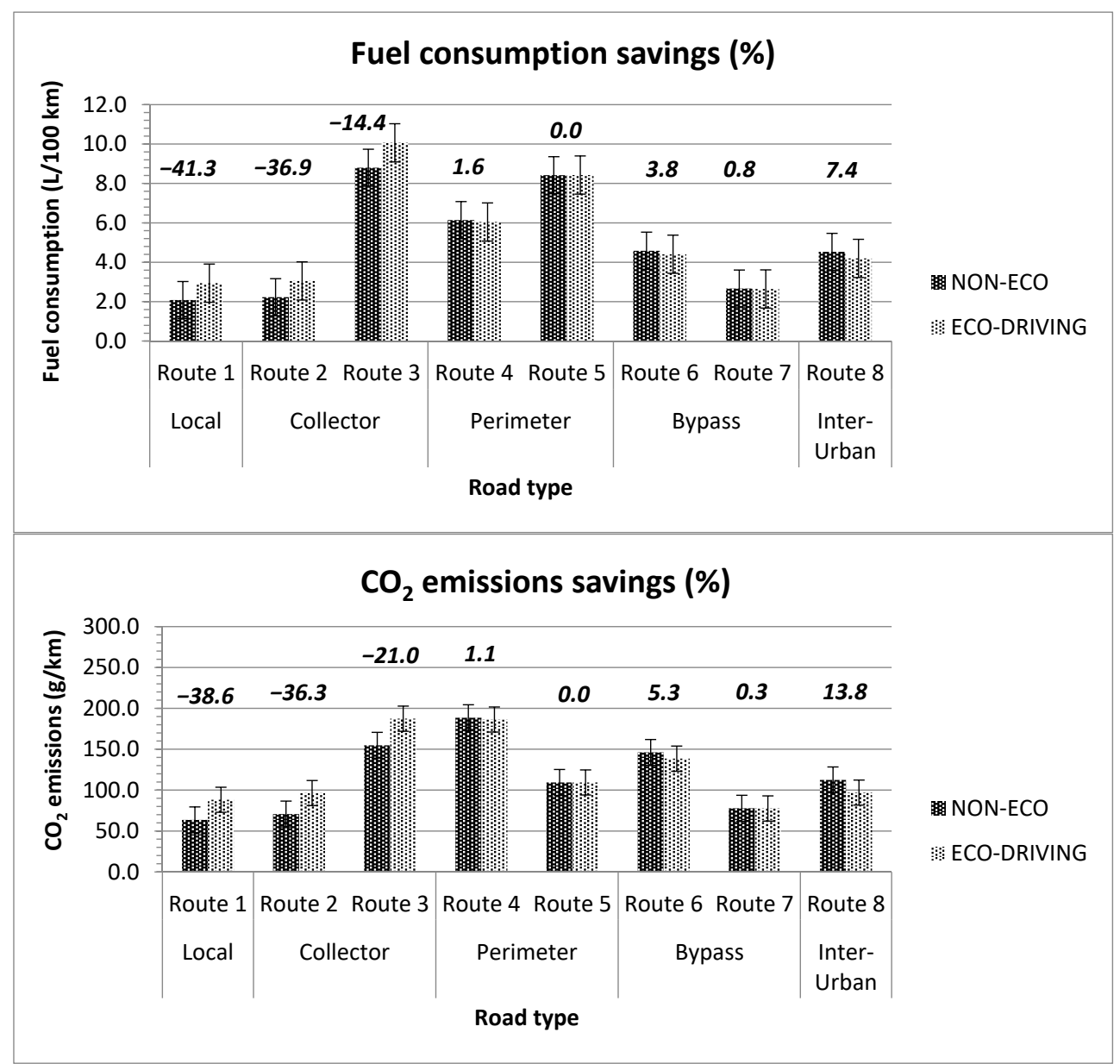

Figure 9. Micro-trips consumption (figure up) and $\mathrm{CO}_{2}$ savings (figure down). 
Results on micro-trips show that eco-driving is more effective on less congested roads with higher capacity (bypass and inter-urban). Urban roads more prone to traffic congestion (local and collector) are not effective in saving fuel and $\mathrm{CO}_{2}$ emissions in eco mode. With the perimeter as it mixes urban and peri-urban roads, it is unclear whether eco-driving is beneficial. Therefore, professional drivers are recommended to choose the least congested and highest capacity routes to make it more effective.

\subsection{Surveys}

Eco-driving needs driver commitment in order to incorporate it into their daily driving techniques. There are several studies on eco-driving which reveal there is a direct relationship between the personality of the drivers and their environment (physical, psychological and psychosocial characteristics) and how effective this driving mode is $[55,56]$.

Table 9 shows the results of the surveys carried out with professional drivers after the delivery shifts.

Table 9. Survey conducted with drivers on all registered trips.

\begin{tabular}{|c|c|c|c|c|c|c|c|c|c|}
\hline \multirow{2}{*}{ Questions } & \multirow{2}{*}{ Driving Mode } & \multirow{2}{*}{ Surveys No. } & \multicolumn{7}{|c|}{ Answers } \\
\hline & & & 1 & 2 & 3 & 4 & 5 & 6 & 7 \\
\hline Driving has been: & Non-eco & 18 & 15 & 1 & 1 & 1 & 0 & 0 & 0 \\
\hline Easy (1)-Hard (7) & Eco-driving & 15 & 15 & 0 & 0 & 0 & 0 & 0 & 0 \\
\hline Driving environment has been: & Non-eco & 18 & 12 & 2 & 3 & 1 & 0 & 0 & 0 \\
\hline Easy (1)-Hard (7) & Eco-driving & 15 & 10 & 4 & 1 & 0 & 0 & 0 & 0 \\
\hline When driving you were: & Non-eco & 18 & 3 & 1 & 1 & 1 & 2 & 8 & 2 \\
\hline Bored (1)-Amused (7) & Eco-driving & 15 & 3 & 0 & 1 & 0 & 0 & 6 & 5 \\
\hline When driving you were: & Non-eco & 18 & 5 & 8 & 1 & 3 & 1 & 0 & 0 \\
\hline Relaxed (1) -Stressed (7) & Eco-driving & 15 & 6 & 5 & 1 & 0 & 0 & 1 & 2 \\
\hline
\end{tabular}

Most surveys (15 out of 18) considered driving easy. This came as no surprise as they are professional drivers. However, driving conditions were also "easy", which means that traffic congestion and other external agents did not affect the way they drove.

Mood when driving hardly varied between normal driving and eco-driving. Contrary to what might be expected-that professional drivers would get bored when changing their driving style-most surveys (10 out of 15$)$ actually felt amused while driving. Three of them did become bored, but this was the case in both eco and non-eco drives. This seems to indicate that the driving mode professional drivers adopt do not influence their mood.

Finally, we saw if the driving mode stressed the professional driver. The results show that most of them (13 of 15) felt relaxed during both driving modes, which means that eco-driving did not make them more stressed. However, their need to deliver within a certain deadline did cause professional drivers stress and it is very difficult for them to modify their driving style with eco-driving techniques.

\section{Discussion}

\subsection{Research Limitations}

This research studies the efficiency of eco-driving by comparing consumption and $\mathrm{CO}_{2}$ emissions before and after a theoretical driver training. OBD devices have proven not to be very accurate in their measurements, but they have been used in this research as they are very easy to install and provide values that can be used to compare both types of driving.

In order to check the effectiveness of eco-driving techniques, a test should be done on a specific road section and under the same weather and traffic conditions. However, our research seeks to know if eco-driving techniques are effective for professional drivers in their daily deliveries. Therefore, the test must be carried out in real conditions, thus using different types of road and under different weather or traffic conditions. The problem is 
that the results of the study of the efficiency of eco-driving techniques can be influenced by the different levels of traffic congestion and the weather conditions, and not by the driving mode used in the delivery. In future research, it may be good to carry out the experiment simultaneously with professional drivers who have received training in ecodriving techniques and drivers who have not received this training in order to compare the results with the same traffic and weather conditions.

Test has been made with four drivers in the morning shift and only 1 in the afternoon shift. Correos is a public courier company, so they work mainly during the morning. We also wanted to take data in the afternoon so that in future research we could analyze the efficiency of both shifts separately. On the other hand, drivers' ages ranged from 35 to 60 , but they were all male. It would be necessary to analyze the efficiency of eco-driving by different age groups and also a new test with female drivers to check if the efficiency is similar in all cases or not.

Finally, drivers knew that they were being monitored before and after training. We wanted to know if by modifying the way of driving we could reduce fuel consumption and emissions. We were not able to elucidate if this behavior was maintained over time or was only carried out during the experiment. On the other hand, professional drivers may not be motivated enough to change their driving techniques as they have not been incentivized, so it would be interesting to know if incentives to save fuel (economic and non-economic) would change the results.

\subsection{Results Discussion}

Eco-driving usually reduces speed and acceleration, but in small cities where routes are very short, it does not sufficiently reduce instantaneous consumption, and this means longer driving times produce higher average fuel consumption $(\mathrm{L} / 100 \mathrm{~km})$ and, as a consequence, higher $\mathrm{CO}_{2}$ emissions. This assertion is in keeping with Schall et al. [38], as they did not observe any savings in fuel consumption with eco-driving with a courier in Munich (Germany). However, these results clashed with most research carried out so far with non-professional drivers, since they show favorable results in consumption with eco-driving in both large and small cities, e.g., Dahou [57] reached fuel savings of approximately $20 \%$ with eco-driving in 10 cities in Tunisia. Furthermore, Andrieu et al. [58] obtained fuel savings of $11.3 \%$ in Pontchartrain, a small town in France. Tests carried out with simulators have also obtained good results with fuel savings of $5 \%$ reaching values of 20-40\% with automated vehicles [59].

Results on micro-trips show that eco-driving is more effective on less congested roads with higher capacity (bypass and inter-urban). Therefore, professional drivers are recommended to choose the least congested and highest capacity routes to make it more effective. Coloma et al. in Caceres [60], and later Yang et al. in Madrid [61], obtained similar results to those found in this research, as fuel savings increased with road capacity. However, there are also other studies [62] which show that high capacity but congested roads are inefficient with eco-driving.

Surveys seems to indicate that the driving mode professional drivers adopt do not influence their mood. In contrast, with other research with non-professional drivers, driver boredom rose by $15 \%$ when driving in eco mode [60]. On the other hand, eco-driving did not make drivers more stressed. Garcia et al. [63] observed that non-professional drivers did not become more stressed when they drove in eco mode either. Nevertheless, their driving was more efficient (in fuel savings and $\mathrm{CO}_{2}$ emissions) when drivers were younger, so driving schools need to provide training in these techniques [64].

\section{Conclusions and Future Research}

Developed countries try to promote efficient road management by using technologies that reduce GHG emissions in cities, implementing driving modes for drivers and sustainable travel decisions. Cities have different methods for achieving these environmental goals, but none can be reached successfully without driver cooperation. Environmental 
policies must be accepted by the general public, and some of them fundamentally depend on the way they drive (eco-driving) and how they plan their trips (eco-routing). Research to date on eco-driving has generally focused on large cities due to their severe congestion problems. Nevertheless, small cities also face these issues and must help reduce GHG emissions, which is a worldwide objective.

In this research, a study was performed on the effectiveness of eco-driving with professional couriers in a small and non-congested city such as Caceres. The results obtained confirmed that eco-driving with courier delivery does not generally lead to average fuel savings per vehicle. An analysis on micro-trips reflects a trend in fuel savings as road capacity increases. Figure 10 summarizes the main conclusions from this research.

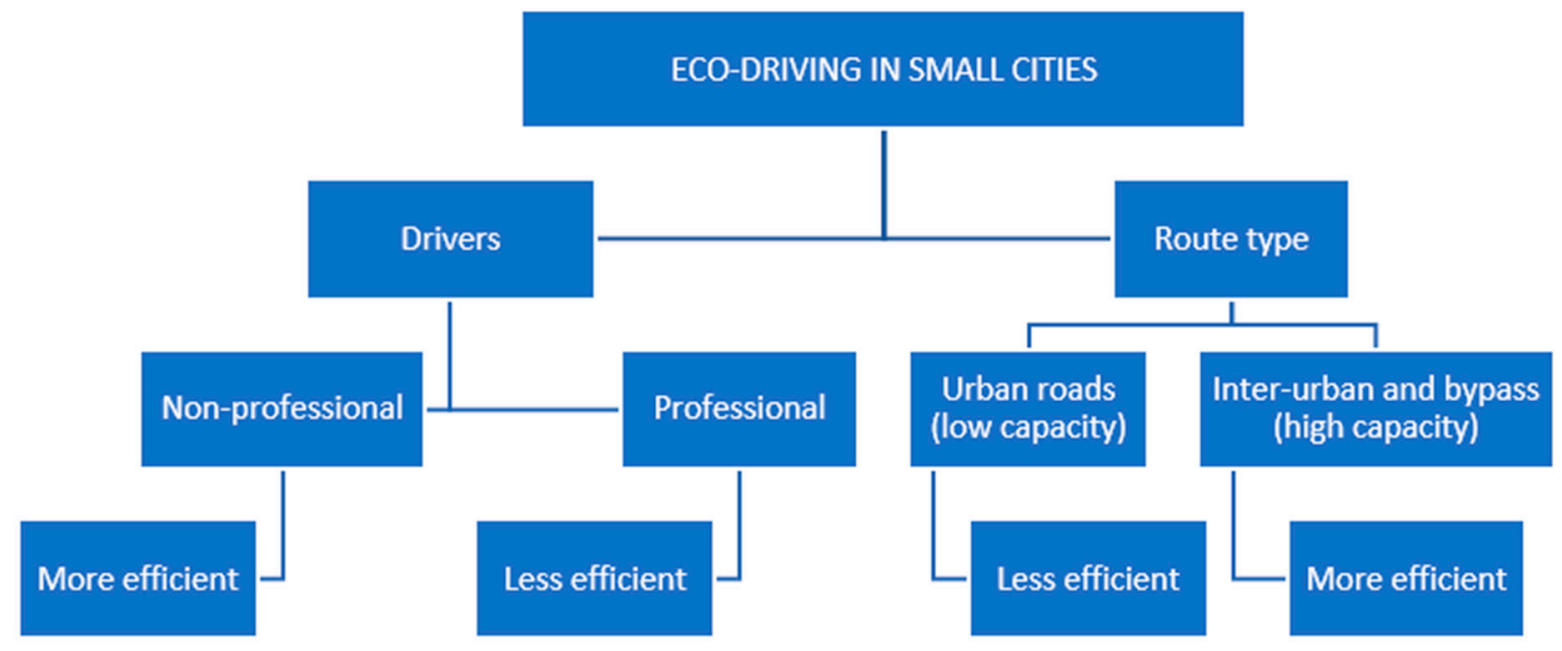

Figure 10. Main conclusions from the research.

In future research, the effects of eco-driving on professional drivers could be studied with incentives (monetary and non-monetary) as Schall and Mohnen [65] achieved fuel savings of around $5 \%$ with the drivers of a fleet company who had received incentives. Other types of vehicle widely used in courier delivery such as motorcycles could be studied as well [66]. Moreover, the effect of eco-driving in electric vehicles also needs to be observed. These kinds of studies require theoretical models for energy consumption such as Vehicle Specific Power (VSP) [67].

Author Contributions: J.F.C. wrote the manuscript. M.G. headed the experiment with Correos and created some of the tables and figures. G.F. processed and filtered the data base and A.M. coordinated the research, reviewed the manuscript, and proposed changes and improvements to its structure. All authors have read and agreed to the published version of the manuscript.

Funding: This work was partly funded by the national R \& D programmer (Ministerio de Economía y Competitividad) under the Eco-Traffic Project "Medición y Modelización de Eco-Driving táctico y operacional". Ref TRA2016-76485-R (AEI/FEDER, UE).

Data Availability Statement: The data used to support the findings of this study may be released upon application to the "Centro de Investigación del transporte," who can be contacted at Centro de Investigación del Transporte Universidad Politécnica de Madrid Escuela de Ingenieros de Caminos, Canales y Puertos c/Profesor Aranguren, 328040 Madrid; 913366656 (Juan Francisco Coloma. jfcoloma@unex.es and http:/ /www.ecotraffic.transyt-projects.es).

Acknowledgments: The authors would like to thank Correos for their support in the data collection process.

Conflicts of Interest: The authors declare no conflict of interest. 


\section{Appendix A. Eco-Driving Course Content}

1. Transportation and energy issues.
1.1. Energy consumption in Spain.
1.2. Problems generated by $\mathrm{CO}_{2}$ emissions.

2. Fundamentals of fuel consumption.

2.1. Fuel consumption in road transport.

2.2. Energy saving in transport.

3. Use of engine and its relationship with consumption.

3.1. Efficient driving concept (Eco-driving). Contributions of eco-driving.

3.2. The energy flow in the vehicle. Fuel consumption and power.

3.3. Idle effect.

3.4. Drag.

4. Explanation of eco-driving techniques. The driver's attitude.

4.1. Prominence of the driver's attitude.

4.2. Concepts associated with eco-driving and main rules.

4.3. Relationship between fuel consumption and speed.

4.4. Fuel savings in high gears.

5. Eco-driving from the vehicle point of view. Practical training.

5.1. Sections with slope positive or negative.

5.2. Curves.

5.3. Use of air conditioning, vehicle window, tire pressure, engine maintenance, vehicle load and accessories.

\section{Appendix B. Survey Template}

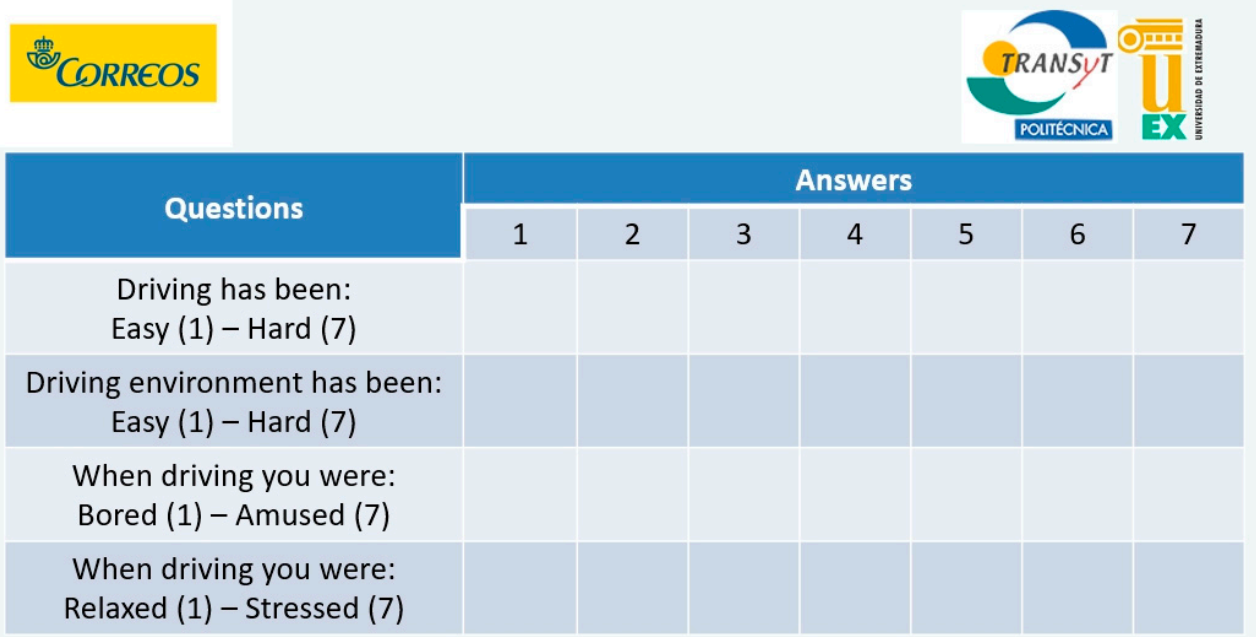

\section{References}

1. European Environment Agency. EEA Greenhouse Gas-Data Viewer. 2019. Available online: https://www.eea.europa.eu/dataand-maps / data / data-viewers / greenhouse-gases-viewer (accessed on 28 October 2020).

2. European Environment Agency. Transport $\mathrm{CO}_{2}$ Emissions in the EU. Emissions Breakdown by Transport Mode. 2016. Available online: https:/ / www.europarl.europa.eu/news/en/headlines/society/20190313STO31218/co2-emissions-from-cars-facts-andfigures-infographics (accessed on 19 December 2020).

3. United Nations. Climate Change Conference COP 21. 2015. Available online: https:/ / ec.europa.eu/clima/policies/international/ negotiations / paris_en (accessed on 28 October 2020). 
4. United Nations. Environment Programme. 2019. Available online: https://www.unenvironment.org/news-and-stories/pressrelease/cut-global-emissions-76-percent-every-year-next-decade-meet-15degc (accessed on 28 October 2020).

5. United Nations. Climate Change Conference COP 25. 2019. Available online: https://unfccc.int/cop25 (accessed on 28 October 2020).

6. Miteco. Ministerio para la Transición Ecológica y el Reto Demográfico. El Sector del Transporte. 2020. Available online: https: //www.miteco.gob.es/es/cambio-climatico/temas/mitigacion-politicas-y-medidas/transporte.aspx (accessed on 28 October 2020).

7. Pérez, P.Y.A.M.; Monzón, A. Informe Sobre Transporte y Medio Ambiente. Trama 2008; Centro de Publicaciones Secretaría General Técnica Ministerio de Medio Ambiente: Madrid, Spain, 2008; Volume 34.

8. Miteco. Ministerio para la Transición Ecológica y el Reto Demográfico. Emisiones de Gases de Efecto Invernadero de los Sectores Difusos. 2020. Available online: https://www.miteco.gob.es/es/cambio-climatico/temas/mitigacion-politicas-y-medidas / definicion-difusos.aspx (accessed on 28 October 2020).

9. Demir, E.; Bektaş, T.; Laporte, G. A review of recent research on green road freight transportation. Eur. J. Oper. Res. 2014, 237, 775-793. [CrossRef]

10. Natural \& Bio Gas Vehicle Association (NGVA) Europe. Greenhouse Gas Intensity of Natural Gas. 2017. Available online: https://gasnam.es/wp-content/uploads/2018/10/NGVA-thinkstep_GHG_Intensity_of_NG_Final_Report_v1.0.pdf (accessed on 28 October 2020).

11. European Commission. COM (2017) 676. Proposal for a Regulation of The European Parliament and of The Council Setting Emission Performance Standards for New Passenger Cars and for New Light Commercial Vehicles as Part of the Union's Integrated Approach to Reduce $\mathrm{CO}_{2}$ Emissions from Light-Duty Vehicles and Amending Regulation (EC) No 715/2007. 2017. Available online: https:/ / eur-lex.europa.eu/legal-content/EN/ALL/?uri=CELEX\%3A52017PC0676R\%2801\%29 (accessed on 28 October 2020).

12. IDAE. Conducción Eficiente de Vehículos Industriales. 2011. Available online: https://www.idae.es/sites/default/files/ publications/online/gce001/index.html (accessed on 28 October 2020).

13. Ecowill Final Report. The Golden Rules of Eco-Driving. 2013. Available online: https://ec.europa.eu/energy/intelligent/ projects/sites/iee-projects/files/projects/documents / ecowill_final_publishable_report_en.pdf (accessed on 26 October 2020).

14. Sivak, M.; Schoettle, B. Eco-driving: Strategic, tactical, and operational decisions of the driver that influence vehicle fuel economy. Transport Policy 2012, 22, 96-99. [CrossRef]

15. Alam, M.S.; McNabola, A. A critical review and assessment of Eco-Driving policy \& technology: Benefits \& limitations. Transport Policy 2014, 35, 42-49. [CrossRef]

16. Kamal, M.A.S.; Mukai, M.; Murata, J.; Kawabe, T. Model predictive control of vehicles on urban roads for improved fuel economy. IEEE Trans. Control Syst. Technol. 2012, 21, 831-841. [CrossRef]

17. Coloma, J.F.; Garcia, M.; Boggio-Marzet, A.; Monzon, A. Developing Eco-Driving Strategies considering City Characteristics. J. Adv. Transp. 2020, 2020,1-13. [CrossRef]

18. Ericsson, E.; Larsson, H.; Brundell-Freij, K. Optimizing route choice for lowest fuel consumption-potential effects of a new driver support tool. Transp. Res. Part C 2006, 14, 369-383. [CrossRef]

19. Boriboonsomsin, K.; Dean, J.; Barth, M. Examination of attributes and value of ecologically friendly route choices. Transp. Res. Rec. 2014, 2427, 13-25. [CrossRef]

20. Ko, B.; Cui, L.; Choi, S.; Park, B.B.; Ryu, S. Field Evaluation of vehicle to infrastructure communication-based eco-driving guidance and eco-signal system. Transp. Res. Rec. 2018, 2672, 123-138. [CrossRef]

21. Ho, S.H.; Wong, Y.D.; Chang, V.W.C. What can eco-driving do for sustainable road transport? Perspectives from a city (Singapore) eco-driving programme. Sustain. Cities Soc. 2015, 14, 82-88. [CrossRef]

22. Coloma, J.F.; Garcia, M.; Wang, Y.; Monzon, A. Environmental Strategies for Selecting Eco-Routing in a Small City. Atmosphere 2019, 10, 448. [CrossRef]

23. Pandazis, J.C.; Winder, A. Study of Intelligent Transport Systems for reducing $\mathrm{CO}_{2}$ emissions for passenger cars. Eur. Road Transp Telemat. Implement. Coord. Organ. 2015, 1, 49. Available online: https://erticonetwork.com/wp-content/uploads/2015/09/ITS4 rCO2-Report-Final-2015-09-10-submitted.pdf (accessed on 26 October 2020).

24. Zarkadoula, M.; Zoidis, G.; Tritopoulou, E. Training urban bus drivers to promote smart driving: A note on a Greek eco-driving pilot program. Transp Res. Part D Transport. Environ. 2007, 12, 449-451. [CrossRef]

25. Thijssen, R.J.T.G.; Hofman, T.; Ham, J. Ecodriving acceptance: An experimental study on anticipation behavior of truck drivers. Transp. Res. Part F Traffic Psychol. Behav. 2014, 22, 249-260. [CrossRef]

26. Strömberg, H.K.; Karlsson, I.M. Comparative effects of eco-driving initiatives aimed at urban bus drivers-Results from a field trial. Transp. Res. Part D Transport Environ. 2013, 22, 28-33. [CrossRef]

27. Daun, T.J.; Braun, D.G.; Frank, C.; Haug, S.; Lienkamp, M. Evaluation of driving behavior and the efficacy of a predictive ecodriving assistance system for heavy commercial vehicles in a driving simulator experiment. In Proceedings of the 16th International IEEE Conference on Intelligent Transportation Systems, The Hague, The Netherlands, 6-9 October 2013; IEEE: Piscataway, NJ, USA, 2013; pp. 2379-2386. [CrossRef]

28. Rutty, M.; Matthews, L.; Andrey, J.; Del Matto, T. Eco-driver training within the City of Calgary's municipal fleet: Monitoring the impact. Transp. Res. Part D Transp. Environ. 2013, 24, 44-51. [CrossRef] 
29. Rionda, A.; Pañeda, X.G.; García, R.; Díaz, G.; Martínez, D.; Mitre, M.; Arbesú, A.; Marín, I. Blended learning system for efficient professional driving. Comput. Educ. 2014, 78, 124-139. [CrossRef]

30. Sullman, M.J.; Dorn, L.; Niemi, P. Eco-driving training of professional bus drivers-Does it work? Transp. Res. Part C Emerg. Technol. 2015, 58, 749-759. [CrossRef]

31. Rolim, C.; Baptista, P.; Duarte, G.; Farias, T.; Pereira, J. Real-time feedback impacts on eco-driving behavior and influential variables in fuel consumption in a lisbon urban bus operator. IEEE Trans. Intell. Transp. Syst. 2017, 18, 3061-3071. [CrossRef]

32. Basarić, V.B.; Jambrović, M.; Miličić, M.B.; Savković, T.M.; Basarić, Đ.M.; Bogdanović, V.Z. Positive effects of eco-driving in public transport: A case study of the city Novi Sad. Therm. Sci. 2017, 21, 683-692. [CrossRef]

33. Pozueco, L.; Tuero, A.G.; Pañeda, A.G.; Pañeda, X.G.; Melendi, D.; García, R.; Diaz Orueta, G.; Rionda, A. Analytic System to Evaluate Efficient Driving Programs in Professional Fleets. IEEE Trans. Intell. Transp. Syst. 2018, 20. [CrossRef]

34. Yao, Y.; Zhao, X.; Ma, J.; Liu, C.; Rong, J. Driving Simulator Study: Eco-Driving Training System Based on Individual Characteristics. Transp. Res. Rec. 2019, 2673, 463-476. [CrossRef]

35. Savković, T.; Gladović, P.; Miličić, M.; Pitka, P.; Ilić, S. Effects of eco-driving training: A pilot program in belgrade public transport. Teh. Vjesn. 2019, 26, 1031-1037. [CrossRef]

36. Evin, E.; Aydin, M.B.; Kardas, G. Design and Implementation of a CANBus-Based Eco-Driving System for Public Transport Bus Services. IEEE Access 2020, 8, 8114-8128. [CrossRef]

37. Vagg, C.; Brace, C.J.; Hari, D.; Akehurst, S.; Poxon, J.; Ash, L. Development and field trial of a driver assistance system to encourage eco-driving in light commercial vehicle fleets. IEEE Trans. Intell. Transp. Syst. 2013, 14, 796-805. [CrossRef]

38. Schall, D.L.; Wolf, M.; Mohnen, A. Do effects of theoretical training and rewards for energy-efficient behavior persist over time and interact? A natural field experiment on eco-driving in a company fleet. Energy Policy 2016, 97, 291-300. [CrossRef]

39. OBD-Key; KBM Systems Ltd.: London, UK, 2019; Available online: http:/ / www.obdkey.com/ (accessed on 28 October 2020).

40. Barth, M.; Boriboonsomsin, K. Energy and emissions impacts of a freeway-based dynamic eco-driving system. Transp. Res. Part. D 2009, 14, 400-410. [CrossRef]

41. UNESCO (United Nations, Educational, Scientific and Cultural Organization). Ciudades Patrimonio de la Humidad. 2020. Available online: http:/ / www.ciudadespatrimonio.org/ciudades/index.php?cd=3 (accessed on 26 October 2020).

42. Ayuntamiento de Cáceres. Plan de Infraestructuras para la Movilidad Urbana Sostenible. 2014. Available online: http: // zetaestaticos.com/comun/upload/0/580/580017.pdf (accessed on 26 October 2020).

43. Ayuntamiento de Cáceres. Estudio de Tráfico y Movilidad. Revisión y Adaptación del Plan General Municipal de Cáceres. 2010. Available online: http://sig.caceres.es/PGM2010/TOMO_VI_EST_TRAFICO/ESTUDIO_DE_TRAFICO_REFUNDIDO.pdf (accessed on 26 October 2020).

44. U.S. Department of Transportation. Highway Functional Classification: Concepts, Criteria and Procedure. 2013. Available online: https: / www.fhwa.dot.gov/planning/processes/statewide/related/highway_functional_classifications/fcauab.pdf (accessed on 26 October 2020).

45. Dirección General de Tráfico. Parque de Vehículos. 2019. Available online: http://www.dgt.es/es/seguridad-vial/estadisticas-eindicadores/parque-vehiculos/tablas-estadisticas/ (accessed on 26 October 2020).

46. Instituto para la Diversificación y Ahorro de la Energía (IDAE). Consumo de Carburante y Emisiones de $\mathrm{CO}_{2}$ en Coches Nuevos. 2017. Available online: http:/ / coches.idae.es/base-datos/marca-y-modelo (accessed on 26 October 2020).

47. Torque Pro and Lite; Ian J Hawkins: Buckinghamshire, UK, 2019; Available online: https://torque-bhp.com/ (accessed on 26 October 2020).

48. Coloma, J.F.; García, M.; Wang, Y. Eco-driving effects depending on the travelled road. Correlation between fuel consumption parameters. Transp. Res. Procedia 2018, 33, 259-266. [CrossRef]

49. Lois, D.; Wang, Y.; Boggio-Marzet, A.; Monzon, A. Multivariate analysis of fuel consumption related to eco-driving: Interaction of driving patterns and external factors. Transp Res. Part D Transport. Environ. 2019, 72, 232-242. [CrossRef]

50. QGIS. 2020. Available online: https://www.qgis.org/es/site/ (accessed on 26 October 2020).

51. Huang, Y.; Ng, E.C.Y.; Zhou, J.L.; Surawski, N.C.; Chan, E.F.; Hong, G. Eco-driving technology for sustainable road transport: A review. Renew. Sustain. Energy Rev. 2018, 93, 596-609. [CrossRef]

52. Saito, A.; Ueki, S.; Nagatomi, Y.; Sawazu, N.; Takada, Y. Analysis of $\mathrm{CO}_{2}$ Reduction Mechanism by Eco-Driving with Light Duty Diesel Freight Vehicle in Real Traffic Conditions; SAE Technical Paper No. 2008-01-1304; SAE International: Warrendale, PA, USA, 2008. [CrossRef]

53. Beusen, B.; Broekx, S.; Denys, T.; Beckx, C.; Degraeuwe, B.; Gijsbers, M.; Scheepers, K.; Govaerts, L.; Torfs, R.; Panis, L.I. Using on-board logging devices to study the longer-term impact of an eco-driving course. Transp. Res. Part. D Transp. Environ. 2009, 14, 514-520. [CrossRef]

54. Garcia-Castro, A.; Monzon, A. Using floating car data to analyse the effects of its measures and eco-driving. Sensors 2014, 14, 21358-21374. [CrossRef] [PubMed]

55. Muslim, N.H.; Keyyanfar, A.; Shafaghat, A.; Abdullahi, M.M.; Khorami, M. Green driver: Travel behaviors revisited on fuel saving and less emission. Sustainability 2018, 10, 325. [CrossRef]

56. Keyvanfar, A.; Shafaghat, A.; Muhammad, N.Z.; Ferwati, M.S. Driving behaviour and sustainable mobility-policies and approaches revisited. Sustainability 2018, 10, 1152. [CrossRef] 
57. Dhaou, I.B. Fuel estimation model for ECO-driving and ECO-routing. In Proceedings of the IEEE Intelligent Vehicles Symposium (IV), Baden-Baden, Germany, 5-9 June 2011; IEEE: Piscataway, NJ, USA, 2011; pp. 37-42. Available online: https: / /ieeexplore.ieee.org/iel5/5930385/5940387/05940399.pdf?casa_token=KG5tg6SKWwEAAAAA:uVGZHoqK_AMm6 TLQZzbdY322J_qkNS6cRLey3R4b9Hjr0XJvl2Jk5alOm3L_vqbSgZCxN-Ztjdo (accessed on 29 October 2020).

58. Andrieu, C.; Saint Pierre, G. Comparing effects of eco-driving training and simple advices on driving behavior. Procedia Soc. Behav. Sci. 2012, 54, 211-220. [CrossRef]

59. Cui, L.; Park, B. Assessing eco-driving behaviors using driving simulator. In Proceedings of the 96th Annual Meeting of the Transportation Research Board, Washington, DC, USA, 7-11 January 2017; Available online: https:/ / www.researchgate.net/ profile/Lian_Cui2/publication/326106819_Assessing_Eco-Driving_Behaviors_Using_Driving_Simulator/links/5d8b0376928 51c33e938bda9/Assessing-Eco-Driving-Behaviors-Using-Driving-Simulator.pdf (accessed on 5 January 2021).

60. Coloma, J.F.; García, M.; Wang, Y.; Monzón, A. Green Eco-driving effects in non-congested cities. Sustainability 2018, 10, 28. [CrossRef]

61. Wang, Y.; Boggio-Marzet, A. Evaluation of Eco-Driving Training for Fuel Efficiency and Emissions Reduction According to Road Type. Sustainability 2018, 10, 3891. [CrossRef]

62. Perez-Prada, F.; Monzon, A. Ex-post environmental and traffic assessment of a speed reduction strategy in Madrid's inner ring-road. J. Transp. Geogr. 2017, 58, 256-268. [CrossRef]

63. García, M.; Coloma, J.F.; Wang, Y. Eco-Driving In Small Cities. Driving Performance In Relation To Driver's Profile. Transp. Res. Procedia 2018, 33, 267-274. [CrossRef]

64. Strömberg, H.; Karlsson, I.M.; Rexfelt, O. Eco-driving: Drivers' understanding of the concept and implications for future interventions. Transport Policy 2015, 39, 48-54. [CrossRef]

65. Schall, D.L.; Mohnen, A. Incentives for energy-efficient behavior at the workplace: A natural field experiment on eco-driving in a company fleet. Energy Procedia 2015, 75, 2626-2634. [CrossRef]

66. Seedam, A.; Satiennam, T.; Radpukdee, T.; Satiennam, W.; Ratanavaraha, V. Motorcycle on-road driving parameters influencing fuel consumption and emissions on congested signalized urban corridor. J. Adv. Transp. 2017, 5859789. [CrossRef]

67. Pitanuwat, S.; Aoki, H.; Iizuka, S.; Morikawa, T. Development of Hybrid-Vehicle Energy-Consumption Model for Transportation Applications-Part I: Driving-Power Equation Development and Coefficient Calibration. Energies 2020, 13, 476. [CrossRef] 